В. С. Калашник, М. І. Філон

\title{
ЛЕКСИКО-СЕМАНТИЧНА ГРУПА 3 КОРЕНЕМ -КРАС- В УКРАЇНСЬКОМУ ЛІНГВОКУЛЬТУРНОМУ ПРОСТОРІ
}

Калашник В. С., Філон М. І. Лексико-семантична група 3 коренем -крас- в українському лінгвокультурному просторі.

У статті розглянуто склад лексико-семантичної групи 3 коренем -крас- в українському лінгвокультурному просторі, означеному різними дискурсами. Наголошено на історичній тяглості та функціональній значущості аналізованих одиниць у формуванні фрагментів національної мовної картини світу. Звернено увагу на семантичну поліфонію відповідних номінацій та домінування естетичних оцінок у сучасних значеннях слів різної тематичної належності.

Ключові слова: лексико-семантична група, номінація, значення, оцінка, народна мова, лінгвокультурний простір. 
Калашник В. С., Филон Н.И. Лексико-семантическая группа с корнем -крас- в украинском лингвокультурном пространстве.

В статье рассмотрен состав лексико-семантической группы с корнем -крас- в украинском лингвокультурном пространстве, обозначенном разными дискурсами. Сделан акцент на исторической преемственности и функциональной значимости анализируемых единиц в формировании фрагментов национальной языковой картины мира. Обращено внимание на семантическую полифонию соответствующих номинаций и доминирование эстетических оценок в современных значениях слов разной тематической принадлежности.

Ключевые слова: лексико-семантическая группа, номинация, значение, оценка, народная речь, лингвокультурное пространство.

Kalashnyk V. S., Filon M. I. Lexical-semantic Group with the Root -kras- in Ukrainian Lingvo-cultural Space.

The paper deals with the composition of the lexical-semantic group with the root -kras- in Ukrainian lingvo-cultural space, denoted by different discourses. The historic succession and functional significance of the analyzed items in formation of fragments of the national language picture of the world are emphasized. The attention is paid to semantic polyphony of the nomination and dominance of esthetic valuation in contemporary meanings of the words of different topical groups.

Key words: lexical-semantic group, nomination, meaning, valuation, folk language, lingvo-cultural space.

Однією з розлогих лексико-семантичних груп, що має праслов'янські витоки, у сучасній українській мові, є група з базовим коренем -крас-, представленим у слові краса. 3 різних етимологічних версій останнього видається найбільш переконливим пояснення О. Трубачова, згідно з яким «слав. *krasa (подобно *kara, *slava, *trava и др.) имеет признаки типичного и.-е. отглагольного имени с долгим (продленным корневым гласным $a(* \bar{o})$, построенного на базе глагола с корневым e» [22, с. 96]. Семантично *krasa реконструюється дослідником як 'колір життя', звідки - колірна ознака 'красний, рум'янець (обличчя)', 'цвітіння, квіт (рослин)' і найбільш загальне 'красота'. Лексика 3 коренем -крас-, наявна в усіх слов'янських мовах, демонструє розмаїття значень, функціональну багатоплановість, полідискурсивність.

Пам'ятки української мови свідчать про безперечну значущість номінацій аналізованої групи в іiі історичній тяглості. Прикметними 3 цього погляду видаються матеріали «Словника староукраїнської мови $\mathrm{XIV-XV} \mathrm{ст.»,} \mathrm{де} \mathrm{подано} \mathrm{близько} 10$ слів із коренем -крас- та словосполук із відповідними словами: Красилов (назва села у Волинській землі), Красная (назва річки у Молдавському князівстві), Краснє (назва села на Буковині), Красное (назва села у Волинській землі), красносельскии монастыръ, красныли поток (у Молдавському князівстві), красная правда - оучинити красную правду, Красныли торгъ (назва міста у Молдавському князівстві), Красныши, Краснєшь (особова назва, молд., слов. красьнъ) - пан Краснєшь дворнык [13, с. 510-511]. Уже 3 поданих ілюстрацій видно тематичну неоднорідність одиниць, належних до означеної лексико-семантичної групи, а довідки щодо мотивації подібних назв, наведені в «Етимологічному словнику літописних географічних назв Південної Русі» [4, с. 73], засвідчують семантичну поліфонію форманта -крас-.

У сучасній українській мові номінації з коренем -крас- виражають естетичну оцінку, що стосується людини, предмета, явища (краса, красен, 
красень, красивий, красота, красування, красуватися, красуля, красун, красунець, красунчик, красуня, красунь, красунька, красуха, кращуати, кращенький, кращчий та ін. [14, с. 326-329]); позначають у складі сталих сполук властивості номінованих явищ крізь призму загальноаксіологічної та частковоаксіологічної оцінок (красна дичина, красна дівиця, красна мова, красна риба, красне місие, красне писання, красне письменство, красне слово, красне сонще, красний господар та ін. [там само]); формують численний клас фітонімів (краса - «щириця хвостата», красний горішок «конюшина», красноголовка - «родовик лікарський», краснолоз - «верба гостролиста», красномолочник - «чистотіл звичайний», красноцвітник «золототисячник малий» і т. ін. [16, с. 86]; краса, красоля - «калачики», красновка - «сорт груші», краснюк - «гриби: підосичник, підберезник» $[1$, c. 251]); утворюють розлогу групу власних назв, серед яких насамперед виділяються гідроніми (Красилівка, Красимівка, Красичка, Краска, Красківка, Красна, Красна Кам'янка, Красна Лука, Красний Став, Красничя, Красногірка, Краснопечерна, Краснопілна, Красносілна, Краснянка та ін. [12, с. 280-282]) та ойконіми (Красилів, Красне, Красний Кут, Красний Лиман, Красногірка, Краснопільськ, Краснокутськ, Краснопілля, Краснорічинське, Красноторка та ін. [21, с. 192-195]).

Тематичний склад лексико-семантичної групи 3 коренем -крас- не обмежується наведеними вище підгрупами. Крім них, можна назвати окремі номінації представників тваринного світу (красуля, красула, красуна, крася - «ряба корова») [7, с. 386], краснюк - «чиж» [6, с. 106], краснопірка [14, с. 328] та ін.), кольорової гами, барвників (красний «барвистий», красило [14, с. 328]), назви на позначення сакрального часу та обрядово-ритуальних символів (крашен вечір - «дівич-вечір» [15, с. 77], красна гірка - «народне свято» [5, с. 313], красна субота - «великоднє свято», красні ворота [17, с. 67], крашанка [14, с. 330] і т. ін.). Зауважмо, що наявні у «Словарі української мови» за редакцією Б. Грінченка такі народно-розмовні номінації, як крас, крась - «краса», красітечний - «дуже красивий», красуля, красулька, красуха, красюк - «красень», красунок, красити - «робити красивим», кращішити [11, с. 300-302], не зафіксовано в академічному Словнику, орієнтованому на літературну мову.

Саме в живій народній мові зберігаються найдавніші значення, які відбивають архаїчне світобачення й значною мірою відмінні від сучасних фрагменти мовної картини світу. Так, у номінаціях красночвітник, краснянка, красноголовка, красуха відсутня притаманна багатьом назвам рослин сема 'червоний колір', а фіксується колір загалом через підкреслення здатності рослини цвісти. 3 цього погляду показовою $\epsilon$ семантика діалектизмів красий - «строкатий», «рябий» (про тварин) [3, с. 104], красний - «багатобарвний» [9, с. 86]. Незвичним для стереотипної картини світу $є$ діалектне значення «великий» у слові красний [там само]. Отже, велика кількість лексичних одиниць із 
коренем -крас- $є$ народними назвами, які представлені в лексикографічних працях, присвячених описові словникового складу різних говірок української мови. До наведених вище можна додати деякі номінації зі «Словника нижньонаддніпрянських говорів» В. Чабаненка: красавицяя, красавка, красавочка, красавчик [20, с. 211], де не важко помітити, зокрема, інтерферентні сліди впливу російських відповідників.

У своїй сукупності весь матеріал має безсумнівне значення для виявлення взаємодії хронологічно різних шарів його семантики, що детермінує особливості входження тих номінацій в український лінгвокультурний простір та визначає їх місце і роль у національній мовній картині світу.

Видається актуальним зосередити увагу на характеристиці одиниць досліджуваної групи, семантика яких вирізняється великою кількістю належних до всіх повнозначних частин мови похідних лексем як таких, що i зберігають, і розчленовують значення етимону. Дослідники наголошують на вираженні цим шаром лексики, починаючи 3 найдавніших оригінальних i перекладних пам'яток, сублімованих значень естетичної оцінки ознак предмета, явища, процесу, стану, що сприймаються різними органами чуття [8, с. 212].

Обрана пошукова спрямованість дослідження так чи інакше передбачає залучення до аналізу слів, семантика яких в історикотипологічному плані $\epsilon$ підгрунтям значень із естетичною оцінкою. У семантичній структурі ядерних слів лексико-семантичної групи 3 коренем -крас-, до яких належать краса, красивий з їх прикметними для сучасної літературної мови значеннями, зберігається всеоб'ємність естетичної оцінки, сформованої в глибинах слов'янської культурноісторичної традиції. Відповідна оцінка охоплює властивість гарного, прекрасного як у зовнішньому, так i внутрішньому його виявах. Це стосується й особи, і предмета, і явища та виражається в різних категоріях: предметності, атрибутивності, процесуальності. Загалом зміст поняття краса в сучасному українському лінгвокультурному наповненні демонструє превалювання естетичних смислів над утилітарнопрагматичними оцінками позначуваного.

Естетична домінанта слова краса (красота) максимально виразно проявляється в літературному художньому дискурсі, свідченням чого є, зокрема, відповідні акценти через розлоге поле означувань цього поняття. Так, красиве, прекрасне в житті, у природі, у поведінці людини, розуміння справжньої та несправжньої краси, красива, приваблива зовнішність людини у поетичній мові означуються майже 150 епітетами [2, с. 174-175]. Ці художні епітети виражають широкий спектр ціннісних характеристик краси в пї суб'єктивному, індивідуальному сприйнятті крізь призму позитивного начала, що явно домінує над ситуативною негацією краси. Порівняймо, з одного боку: безсмертна, благородна, Божа, горда, дивна, 
квітуча, лагідна, небесна, несказанна, полум'яна, предковічна, світла, яскрава і т. ін.; з іншого: в яла, груба, зухвала, мертва, фатальна, холодна, чужа. Позитивна оцінка особливо відчутна в епітетах, віднесених упорядниками Словника до оригінальних, наприклад: самоцвітна (Л. Українка), незламно-горда (Ю. Клен), невіддавана (М. Рильський).

На відміну від художнього більш ранні в історико-типологічному плані дискурси не відзначаються очевидним домінуванням естетичної оцінки у складниках лексико-семантичної групи з коренем -крас-. Сучасне сприйняття відповідних номінацій має враховувати особливості мовної картини світу в тому чи тому дискурсі, динаміку ціннісних характеристик для певного типу свідомості, сукупність лінгвоенциклопедичних знань про світ і, зрештою, здатність базових слів краса, красний акумулювати всю сукупність значень, сформованих протягом багатовікової історії.

Міфопоетичний синкретизм семантики символу краса прослідковується в архаїчних жанрах народної словесності, зокрема належних до календарно-обрядової та сімейно-обрядової поезії. У веснянках, наприклад, краса пов'язана з жіночим началом і мислиться як образ, що синтезує смисли «врода», «жіночість», «життєдайність», «цнотливість», як у наведеному нижче уривку: - Та у Рай матку кличе: / - Та подай, матко, ключи, / Одімкнути небо, / Випустити росу, / Дівоцьку красу [див.: 19, с. 492]. Архаїчні витоки міфологічної семантики краси, красного прослідковуються і в весільних піснях, де вони є наскрізними для конструювання фрагментів мовної картини світу, засвідчених обрядовими текстами. Саме ці образи є генералізуючими для вираження провідних ідей весілля, що знаходить своє втілення як у змалюванні обрядодії прощання з красою напередодні весілля, так i в характеристиках учасників обрядового дійства, весільних атрибутів, у часових та просторових позначеннях: крашен вечір; молода красна, красная, красива; молодий красний, дружка красна, дружба красний, дружбове красненькі, поӥз красен, вінець красний, вилечко прекрасне, коровай красний, красніший від зорі [15, с. 186-195]. Одним із найбільш показових для весільної семіосфери символів є дівоча коса, що в текстах весільних пісень входить до складу міфопоетичного комплексу коса - краса - золото: А жемчужа то коса твоя, / А золото - красота твоя [15, с. 143]. Визначення краси через пї ототожнення з коштовностями $\epsilon$ одним із етапів розвитку аналізованого образу.

Функціональний вияв семантики базових для фольклору словообразів із коренем -крас- у весільній поезії демонструє складну взаємодію різних сенсів, на що свого часу звернув особливу увагу О. Потебня, розкриваючи символіку дівочої краси [10, с. 35-36]. Дослідник наголосив, що «красная лента» та «красная фрата» $€$ символом відношення дівочості до світла. 
Міфопоетичні інтенції образу краси зберігаються в численних фразеологізмах, зокрема компаративних, із компонентами красивий, красний. Значущими видаються матеріали збірника «Українські прислів’я, приказки та порівняння з літературних пам'яток», де останні представлені різними виданнями - від давнини до сучасності. Вирази на зразок красивий, наче земля весною; красивий, як весна; красна, як маків цвіт; красна, як сонще на небі; така красна, як сонще; красна, як чічка в городі; красний, як мак і т. ін. [18, с. 37] недвозначно експлікують поняття краса не через червоний колір зокрема і колір загалом, а в його нерозривному зв’язку з цвітінням, життям природи й довколишнього світу або із життєдайним світлом. У порівняльних зворотах пізнішого походження на кшталт красна, як з каменя вибита; красний, як з воску вилитий; красний, як намальований [там само], де об'єктом порівняння є культурні артефакти як символи прекрасного, архаїчні смисли редукуються, а на передній план виходять власне естетичні оцінки.

Як свідчить уся сукупність складників лексико-семантичної групи 3 коренем -крас-, в українському лінгвокультурному просторі краса $\epsilon$ одним із центробіжних образів, що демонструє свою важливу роль при номінуванні широкого кола явищ дійсності і тим самим виявляє свій домінантний характер у формуванні різних сегментів національної мовної картини світу. Акцентованим при цьому є естетичний модус краси, що на семантичному рівні знаходить своє оформлення в парадигмі давніх і нових значень. У сучасних дискурсах функціонування української мови повною мірою проявляється змістова неоднорідність і семантична поліфонія номінацій, належних до розглянутої групи.

\section{Література}

1. Аркушин Г. Л. Словник західнополіських говірок : у 2-х т. - Т. 1 / Г. Л. Аркушин. - Луцьк : Вежа, 2000.

2. Бибик С. П. Словник епітетів української мови / За ред. С. Я. Срмоленко / С. П. Бибик, С. Я. Єрмоленко, Л. О. Пустовіт. - К. : Довіра, 1998.

3. Гуцульські говірки. Короткий словник / Відп. ред. Я. Закревська. - Львів, 1997.

4. Етимологічний словник літописних географічних назв Південної Русі. - К. : Наук. думка, 1985.

5. Жайворонок В. В. Знаки української етнокультури : Словник-довідник / В. В. Жайворонок. - К. : Довіра, 2006.

6. Лисенко П. С. Словник поліських говорів / П. С. Лисенко. - К. : Наук. думка, 1974.

7. Онишкевич М. Й. Словник бойківських говірок. Ч. І / М. Й. Онишкевич. - К. : Наук. думка, 1984.

8. Пименова М. В. Красотою украси: выражение эстетической оценки в древнерусском тексте. СПб ; Владимир, 2007.

9. Піпаш Ю. Матеріали до словника гуцульських говірок / Ю. Піпаш, Б. Галас. - Ужгород, 2005.

10. Потебня А. А. О некоторых символах в славянской народной поэзии / А. А. Потебня. - Харьков, 1914.

11. Словарь української мови / За ред. Б. Грінченка : у 4-х т. - Т. 2. - К., 1908.

12. Словник гідронімів України / Ред. колегія А. П. Непокупний, О. С. Стрижак (заст. голови), К. К. Цілуйко (голова). - К. : Наук. думка, 1979.

13. Словник староукраїнської мови XIV-XV ст. : у 2-х т. - Т. I. - К. : Наук. думка, 1977.

14. Словник української мови : в 11-ти т. - Т. 4. - К. : Наук. думка, 1973.

15. Слюсарева О. В. Епітетика українських весільних обрядових пісень (структурно-семантичний $\mathrm{i}$ функціональний аспекти). Дисертація ... канд. філол. наук, 10.02.01 / Слюсарева Олеся Володимирівна. Харків, 2006.

16. Смик Г. К. Корисні та рідкісні рослини України : Словник-довідник народних назв / Г. К. Смик. К. : Укр. рад енцикл. імені М. П. Бажана, 1991. 
17. Туряєва Н. Словник церковно-обрядової термінології / Н. Туряєва. - Львів : Свічадо, 2001.

18. Українські прислів'я, приказки та порівняння з літературних пам’яток / Упор. М. М. Пазяк. - К. : Наук. думка, 2001.

19. Філон М. Семантика словообразу краса в архаїчних текстах української народної словесності / М. Філон, Г. Губарева // Незгасимий словосвіт : Зб. наук. праць. - Харків : Харк. нац. ун-т імені В. Н. Каразіна, 2011. - С. 490-497.

20. Чабаненко В. А. Словник говірок Нижньої Наддніпрянщини : в 4-х т. Т. 2 / В. А. Чабаненко. Запоріжжя, 1992.

21. Янко М. П. Топонімічний словник України : Словник-довідник / М. П. Янко. - К. : Знання, 1998.

22. Этимологический словарь славянских языков. Праславянский лексический фонд. Вып. 12 / Под ред. О. Н. Трубачева. - М. : Наука, 1985.

Стаття надійшла до редакції 17.10.2011 р. 